\title{
PEMETAAN PARTISIPATIF JALUR EVAKUASI TSUNAMI DI DESA BABANG KABUPATEN HALMAHERA SELATAN MALUKU UTARA
}

\author{
Mohammad Ridwan Lessy ${ }^{1}$, Rohima Wahyuningrum ${ }^{2}$ \\ ${ }^{1}$ Program Studi Ilmu Kelautan, Universitas Khairun. Jalan Yusuf Abdulrahman, Kelurahan \\ Gambesi, Kota Ternate 97719, Indonesia \\ ${ }^{2}$ Program Studi Pendidikan Fisika, Universitas Khairun, Jalan Bandara Baabullah, Kelurahan \\ Akehuda, Kota Ternate 97735, Indonesia \\ Email: ${ }^{1}$ mrlessy8375@gmail.com; ${ }^{2}$ ima.geolive@gmail.com
}

Received: Juni 2020; Accepted : Juni 2020; Published : Juli 2020

\begin{abstract}
Abstrak
Bencana tsunami masih menjadi acaman wilayah pesisir di Indonesia karena intersitas gempabumi yang tinggi di wilayah ini dan singkatnya waktu tempuh gelombang tsunami ke daratan. Untuk itu, warga masyarakat perlu dipersiapkan untuk menghadapi bencana ini dengan menyusun peta jalur evakuasi tsunami. Peta evakuasi disusun secara partisipatif dengan melibatkan semua elemen pemangku kepentingan untuk mendapatkan kesepahaman persepsi antara semua pemangku kepentingan. Tujuan penyusunan peta jalur evakusi untuk memudahkan dan mengarahkan warga melalukan evakuasi mandiri menuju ke tampat yang lebih aman. Peta jalur evakuasi ini akan semakin efektif apabila ditindaklanjuti dengan penyusnan rencana aksi, sosialisasi dan simulasi secara terus menerus untuk mengevaluasi peta yang telah disusun.
\end{abstract}

Kata Kunci: Tsunami, Peta Evakuasi, Maluku Utara

\section{Abstract}

Tsunami is still a serious threat to coastal areas in Indonesia because of the high earthquake intensity in this region and the short travel time of tsunami waves to land. Therefore, the community needs to be prepared to cope with this disaster by arranging a map of the tsunami evacuation route. The evacuation map was prepared in a participatory approach that involving all elements of stakeholders to get a common understanding between all stakeholders. The purpose of preparing the evacuation route map is to facilitate and direct the communities through independent evacuation to a safer place. This evacuation route map will be more effective if followed up with continuous action plans, dissemination, and simulation to evaluate the maps that have been prepared.

Keywords : Tsunami, Evacuation Map, North Maluku

\section{Latar Belakang Masalah}

Kepulauan Wilayah Maluku Utara memiliki struktur geotektonik yang sangat kompleks, hal ini disebabkan karena secara geologis wilayah ini di pengaruhi tiga lempeng besar yaitu lempeng Eurasia lempeng Pasifik dan lempeng Indo-Australia bertemu di wilayah Halmahera [1]. Selain itu, secara geografis wilayah Maluku Utara memiliki wilayah laut yang luas (76\%) dibandingkan dengan wilayah darat (24\%), serta memiliki 395 buah pulau besar dan kecil dan juga terdapat 856 desa pesisir (79\%) dari total jumlah 1.079 desa di Maluku Utara. Kondisi 
tersebut menyebabkan wilayah Maluku Utara tergolong sebagai wilayah yang sensitif terhadap bencana alam serta memiliki tingkat kerawanan yang tinggi diantarnya adalah bencana gempa bumi dan tsunami [2].

Telah diketahui bahwa ancaman bencana tsunami di wilayah pesisir umumnya hanya menyisahkan waktu yang sangat terbatas untuk penyebaran peringatan dini dan melakukan evakuasi. Dalam situasi seperti ini, diperlukan reaksi yang cepat dimana masyarakat di wilayah pesisir harus dibekali dengan kemampuan untuk melakukan evakuasi mandiri dengan cara yang benar dan tepat. Sehingga, diperlukan suatu perencanaan evakuasi yang menjadi bagian terpenting dalam pengurangan risiko bencana. Pengurangan risiko bencana dan perencanaan evakuasi menjadi tanggungjawab semua pemangku kepentingan terutama pemerintah di daerah. Namun demikian, kedua hal tersebut seharusnya melibatkan semua elemen masyarakat dari level bawah hingga kepala desa serta pihak-pihak terkait seperti perguruan tinggi, Lembaga Swadaya Masyarakat (LSM) dan para pakar dibidangnya [3].

Desa Babang merupakan salah satu desa pesisir yang terletak Pulau Bacan, Kabupaten Halmahera Selatan, Provinsi Maluku Utara. Desa ini menjadi salah satu desa yang terdampak pada saat terjadi gempabumi dengan magnitude 7.2 SR di Kabupetan Halmahera Selatan tanggal 14 Juni 2019. Meskipun gempa tersebut tidak membangkitkan tsunami, seluruh masyarakat di desa Babang dan desa-desa pesisir disekitarnya melakukan penyelamatan mandiri dengan mengungsi ke gunung dan wilayah dataran tinggi. Akan tetapi, cara masyarakat menyelamatkan diri masih tidak terkoordinasi dengan baik dan terkesan hanya secara keluarga atau kelompok. Kondisi tersebut menunjukkan bahwa masih ada kelemahan yang terjadi di masyarakat desa Babang terkait dengan pengurangan risiko bencana dan mitigasinya. Berdasarkan hasil analisis di lapangan, kelemahan-kelemahan tersebut antara lain; (1) kurangnya kesadaran, pengetahuan dan partisipasi masyatakat untuk memahami potensi bencana di wilayahnya, (2) masih lemahnya kapasitas masyarakat untuk mengahadapi dampak bencana, (3) belum tersedianya data risiko dan penilain kerentaanan bencana, (4) belum adanya system peringatan dini dan jalur evauasi, (5) issu bencana belum menjadi prioritas dalam usulan pembangunan, serta (6) belum adanya dokumen rencana kontijensi untuk menghadapi bencana. Pada hal menurut [4], bagi suatu daerah yang sering dilanda bencana, pemerintah dan masyarakatnya dituntut untuk memiliki katangguhan dan ketahanan terhadap bencana yang tinggi. Karakteristik masyarakat yang tangguh bencana diantaranya; (1) masyarakat yang mampu memberikan gambaran komprehensif mengenai semua bahaya dan risiko utama yang menghadang masyarakat serta potensi risiko, (2) masyarakat yang memiliki keterampilan dan kapasitas untuk melaksanakan penilaian bahaya dan risiko melalui dukungan dan pelatihan, (3) Memiliki kebijakan Pengurangan Risiko Bencana, strategi dan rencana implementasi, (4) memiliki system peringatan dini yang efektif. Untuk itu, masyatakat di Desa Babang perlu dibantu untuk mandiri dan menjadi desa tangguh bencana. Pada kondisi ini, peran semua elemen masyarakat dan pemangku kepentingan sangat dibutuhkan dalam upaya meningkatkan kesadaran akan bencana sebelum, pada saat dan setelah bencana terjadi.

Berdasarkan hal tersebut, keterlibatan semua pemangku kepentingan termasuk akademisi dituntut untuk mengedukasi masyarakat, agar masyarakat memiliki kemampuan, kapasistas, dan kesiapan terhadap bencana tsunami yang sangat berpotensi disekitar mereka [5]. Untuk itu, program kemitraan masyarakat yang dilaksanakan melalui penguatan kapasitas masyarakat untuk pengurangan risiko bencana dan kegiatan penyusunan peta jalur evakuasi mandiri tsunami di Desa Babang bertujuan untuk (1) meningkatkan pengetahuan masyarakat tentang potensi bencana alam di daerahnya (khususnya tsunami), (2) Meningkatkan berperan aktif masyarakat 
dalam pembuatan jalur evakuasi bencana tsunami dan memiliki kemampuan, kesiapan, dan kapasitas dalam menghadapi bencana tsunami, serta (3) memberikan arahan kepada masyarakat dan pemerintah desa yang berisiko dalam rangka mempersiapkan diri dan bersiaga baik secara individu, keluarga dan juga lembaga.

\section{Metode}

Pelaksanaan kegiatan pemetaan partisipatif jalur evakuasi tsunami dilakukan pada bulan Agustus 2019 dan berlokasi di Desa Babang, Kecamatan Bacan Timur, Kabupaten Halmahera Selatan (Gambar 1).

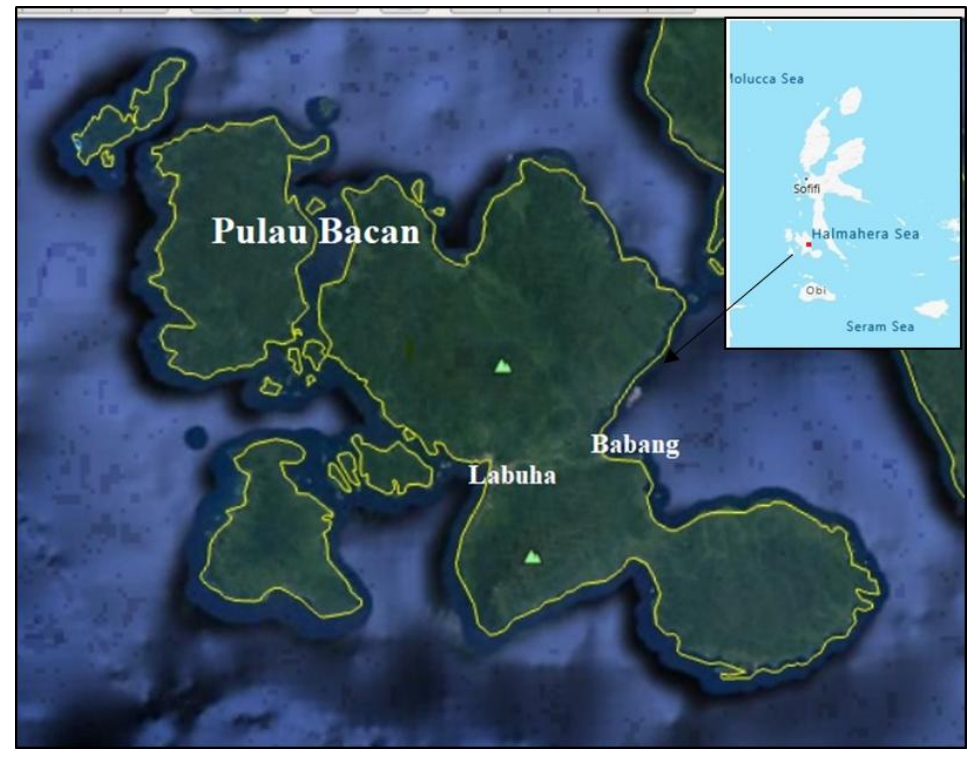

Gambar 1. Peta Lokasi Kegiatan Program Kemitraan Masyarakat

Telah dijelaskan bahwa berbagai persoalan yang dihadapi masyarakat desa Babang terkait pengurangan risiko bencana salah satunya adalah kurangnya pemahaman masyarakat tentang bagiamana mengahadapi bencna terutama melakukan evakuasi pada saat bencana tsunami terjadi serta belum tersedianya peta jalur evakuasi. Oleh karena itu, pelaksanaan kegiatan diawali dengan pengumpulan data yang terdiri dari data primer dan data sekunder. Data primer yang dikumpulkan di lapangan meliputi penggunaan lahan, batas wilayah, infrastruktur dan fasilitas umum desa, serta data elevasi. Sedangkan data sekunder yang digunakan meliputi citra satelit Google Earth yang di kompilasi dengan data citra Bing Maps. Data lainnya yang dikumpulkan adalah data jaringan jalan dan blok bangunan dari layanan Open Street Map. Selanjutnya datadata yang telah terkumpul dibuatkan satu peta dasar dengan bantuan software ArcGIS 10.1. Peta dasar ini kemudian digunakan sebagai acuan untuk mendapatkan informasi dan atribut lainnya pada saat kegiatan Fokus Grup Diskusi (FGD).

Kegiatan selanjutnya adalah FGD dan pemetaan partisipatif. Kedua kegiatan ini melibatkan semua pemangku kepentingan mulai dari kepala desa dan perangkatnya, Ketua BPMD, ketua RT, tokoh agama, tokoh pemuda dan masyarakat lainnya. Menurut [6] FGD bertujuan untuk mengumpulkan data mengenai persepsi dan pandangan peserta terhadap sesuatu sehingga memungkinkan peserta untuk memberikan jawaban yang disertai dengan penjelasan-penjelasan. Oleh karena itu, dalam pelaksanaan FGD pada kegiatan ini bertujuan untuk mendapatkan 
informasi mengenai kesiapsiagaan masyarakat menghadapi bencana, menyamakan persepsi antar semua pemangku kepentingan terkait manajemen bencana termasuk jalur evakuasi yang akan disusun sehingga menjadi suatu pedoman kegiatan mitigasi dan adaptasi dalam hal pengurangan risiko bencana khususnya bencana tsunami berbasis masyarakat di desa Babang. Untuk mengisi kesenjangan yang ada di masyarakat, selama proses FGD dilakukan juga pemaparan materi yang bertujuan untuk meningkatkan pemahaman dan kesiapsiagaan masyarakat menghadapi bencana khususnya bencana tsunami. Topik-topik yang disampaikan antara lain; bencana tsunami dan penyebabnya; panduan singkat mengahadapi bencana tsunami, panduan singkat mitigasi bencana tsunami, dan penyusunan peta evakuasi.

Selajutnya kegiatan pemetaan partisipatif. Kegiatan ini dijelaskan oleh [7]adalah satu metode pemetaan yang menempatkan masyarakat sebagai pelaku pemetaan wilayahnya, sekaligus juga akan menjadi penentu perencanaan pengembangan wilayah mereka sendiri. Pemetaan partisipatif dalam kegiatan ini bertujuan untuk menyusun peta jalur evakuasi yang dihasilkan dari kesepakatan masyarakat secara bersama-sama. Metode pelaksanaan pemetaan partisipatif diawali dengan memaparkan dengan jelas kepada peserta FGD bahwa peta yang akan disusun digunakan untuk penentuan jalur evakuasi bila terjadi tsunami [8]. Parameter parameter yang ada secara tidak langsung dijelaskan dalam alasan pemilihan jalur evakuasi yang diungkapkan oleh masyarakat untuk menentukan jalur evakuasi yang efisien, yaitu kemiringan lereng, Kawasan Rawan Bencana (KRB), panjang jalan, lebar jalan, jenis permukaan jalan, kondisi jalan, arah, dan keberadaan jembatan. Parameter tersebut kemudian dimodelkan dengan bobot tertentu untuk mendapatkan jalur yang paling baik. Kemudian meminta peserta FGD untuk mengubah/ menambahkan atribut apapun yang mungkin salah atau belum ada. Mulai dengan batas desa, mengidentifikasi lokasi penting, nama unit bagian desa berbeda atau pemukiman, jalan utama, sungai besar dan badan air lain. Selanjutnya salinan peta dasar tersebut pada kertas kalkir akan digunakan di seluruh lanjutan praktik pemetaan dengan menumpangsusunkan pada peta dasar.

\section{Hasil dan Pembahasan}

\subsection{Gambaran Umum Lokasi Kegiatan}

Secara administratif, Desa Babang bebatasan di sebelah Utara dengan Desa Sayoang, di sebelah Barat dangan Desa Wayamiga, di sebelah selatan dengan Kecamatan Bacan Timur Tengah, dan di sebelah Timur dengan Selat Patinti. Secara geografis, Desa Babang merupakan desa pesisir dengan luas wilayah $\pm 26 \mathrm{~km}^{2}$. Topografi desa bervariasi mulai dari dataran rendah hingga berlereng/berbukit yang berlanjut dengan pengunungan Sibela dengan ketinggian sekitar 2 - 1000 mdpl [9].

Selanjutnya, dari segi demografi, jumlah penduduk Desa Babang pada tahun 2018 sebanyak 11.792 jiwa yang terdiri dari 6.076 laki-laki dan 5.716 perempuan dengan jumlah kepala keluarga $1.477 \mathrm{kk}$. Untuk klasifikasi bangunan rumah di dominasi oleh rumah sederhana $( \pm 50 \%)$, rumah semi permanen $( \pm 22 \%)$, dan sisanya rumah permanen $( \pm 28 \%)$ [9] .

Sektor pertanian merupakan sektor yang strategis selain karena sebagai sektor yang menjadi penyedia kebutuhan bagi masyarakat, sektor ini juga mampu menyerap tenaga kerja yang banyak terutama di desa Babang. Tercatat sekitar 705 keluarga pertanian dan 42 keluarga buruh tani. Luas lahan pertanian terdata 2.690 Ha dengan komoditi utama adalah kelapa, pala dan kakao.

Hasil pengumpulan data primer dan sekunder di lapangan memperlihatkan bahwa desa Babang mempunyai peranan penting bagi pembangunan terutama sektor ekonomi bagi Pulau Bacan. Hal ini dikarenakan beberapa infrastuktur vital untuk menunjang perekonomian berada di 
desa Babang (Tabel 1). Namun disayangkan bahwa infrastruktur tersebut umumnya dibangun di wilayah pesisir dengan jarak yang cukup dekat dengan garis pantai. Kondisi seperti ini menyebabkan infrastruktur tersebut rawan dan berisiko terhadap bencana tsunami.

Tabel 1. Infrastruktur Vital di Desa Babang

\begin{tabular}{l|l|c}
\hline No. & Infrastruktur & Jumlah \\
\hline \hline 1. & Pelabuhan & 2 \\
2. & Tanki BBM Pertamina & 1 \\
3. & Depot SPBU & 1 \\
4. & Pasar & 1 \\
5. & Terminal & 1 \\
6. & Sekolah (SD,SMP,SMA) & 7 \\
7. & Puskesmas & 1 \\
8. & Rumah Ibadah & 5 \\
\hline
\end{tabular}

\subsection{Kesiapsiagaan Masyarakat Menghadapi Bencana Tsunami}

Kesiapsiagaan menurut Undang-undang nomor 24 tahun 2007 tentang penanggulangan bencana dapat diartikan sebagai serangkaian kegiatan yang dilakukan untuk mengantisipasi bencana melalui pengorganisasian serta melalui langkah yang tepat guna dan berdaya guna. Namun demikian, sampai saat ini bencana tsunami mungkin dianggap sebagai suatu kejadian bencana yang masih menakutkan di Indonesia karena cukup banyak korban yang terdampak serta prediksi gempa yang memicu tsunami masih sering belum akurat dilakukan. Selain itu, kebanyakan tsunami yang terjadi di Indonesia bersifat tsunami local atau tsunami jarak dekat yang tiba di wilayah pesisir dengan cepat karena ditimbulkan oleh gempa bumi yang berpusat di wilayah pantai [10]. Oleh karena itu, masyarakat yang menetap di wilayah pesisir perlu dibekali dengan pengetahuan dasar tentang sebuah perencanaan pengurangan risiko bencana. Dalam perencanaan tersebut, perlu dipertegas tentang apa dan siapa di lokasi bencana serta keberadaan sumberdaya dan potensi local yang tersedia untuk melakukan mitigasi bencana [11].

Berdasarkan hasil FGD terungkap bahwa sebagian besar peserta FGD belum memahami sepenuhnya kesiapsiagaan yang diperlukan untuk menghadapi bencana tsunami termasuk system peringatan dini. Hal ini terlihat dari masih kurangnya pengorganisasian kegiatan kesiapsiagaan yang dilakukan oleh masyarakat dan pemangku kepentingan serta belum tersedianya rencana evakuasi, rencana mitigasi dan adaptasi terhadap bencana tsunami. Sistem peringatan dini yang tersedia belum dibangun sebagaimana mestinya.

Menurut [12], lemahnya kesiapsiagaan bencana di masyarakat dipengaruhi beberapa faktor diantaranya; tingkat pendidikan dan pengalaman, sosial, ekonomi, dan usia. Namun pendidikan dan pengalaman merupakan factor yang utama dimana diharapkan bahwa dengan pendidikan yang tinggi maka semakin luas pula pengetahuannya dan pengalamannya sehingga mempengaruhi sikap dan perilaku seseorang untuk benpartisipasi dalam kesiapsiagaan bencana. Untuk itu, masyarakat dan seluruh pemangku kepentingan perlu didorong dalam proses penyadaran (awareness) dalam peningkatan kemampuan diri sendiri. Proses penyadaran tersebut berguna agar setiap orang dapat memahami risiko, mampu mengelola ancaman dan, pada gilirannya, berkontribusi dalam mendorong ketangguhan masyarakat dari ancaman bahaya bencana. Di samping itu, kohesi sosial, gotong royong, dan saling percaya merupakan nilai perekat modal sosial yang telah teruji dan terus dipupuk, baik kemampuan perorangan dan 
masyarakat secara kolektif, untuk mempersiapkan, merespon, dan bangkit dari keterpurukan akibat bencana [13].

Namun demikian, pemaparan materi yang disampaikan selama kegiatan FGD dan tanya jawab memperlihatkan bahwa masyarkat mulai memahami apa itu bencana tsunami, penyebab dan bagaimana mitigasinya. Kesadaran peserta FGD juga sudah terlihat jelas tentang pentinganya pemahaman mengenai bencana. Hal ini terlihat dari respon peserta FGD berpartisipasi aktif dalam penyusunan peta jalur evakuasi.

\subsection{Pemetaan Partisipatif Jalur Evakuasi}

Partisipasi masyarakat dapat dijelaskan sebagai keterlibatan yang bersifat spontan yang disertai kesadaran dan tanggungjawab dalam suatu proses interaksi yang melibatkan dua kelompok atau unsur masyarakat untuk pengambilan suatu keputusan dan/atau perencanaan dimana proses tersebut menjadi hasil keputusan bersama. Pendekatan partisipasi masyarakat dalam pengurangan risiko bencana didasari oleh Undang-undang nomor 24 tahun 2007 tentang penanggulangan bencana serta Peraturan Pemerintah nomor 21 tahun 2008 tentang penyelenggaran penanggulangan bencana yang merubah paradigma penanggulangan bencana di Indonesia dari konsep tanggap darurat yang bersifat responsif menjadi konsep pengurangan risiko bencana yang bersifat preventif [14]. Dalam undang-undang tersebut, penanggulangan bencana tidak hanya terpusat pada upaya tanggap darurat dan rehabilitasi serta rekonstruksi pasca bencana tetapi lebih diarahkan pada tahapan sebelum terjadinya (pra bencana) melalui upaya peningkatan kapasitas masyarakat terhadap bencana. Sehinggga partisipasi masyarakat sangat penting agar bisa memahami kebutuhan dasar yang diperlukan untuk menghadapi ancaman bencana tsunami di wilayahnya [15].

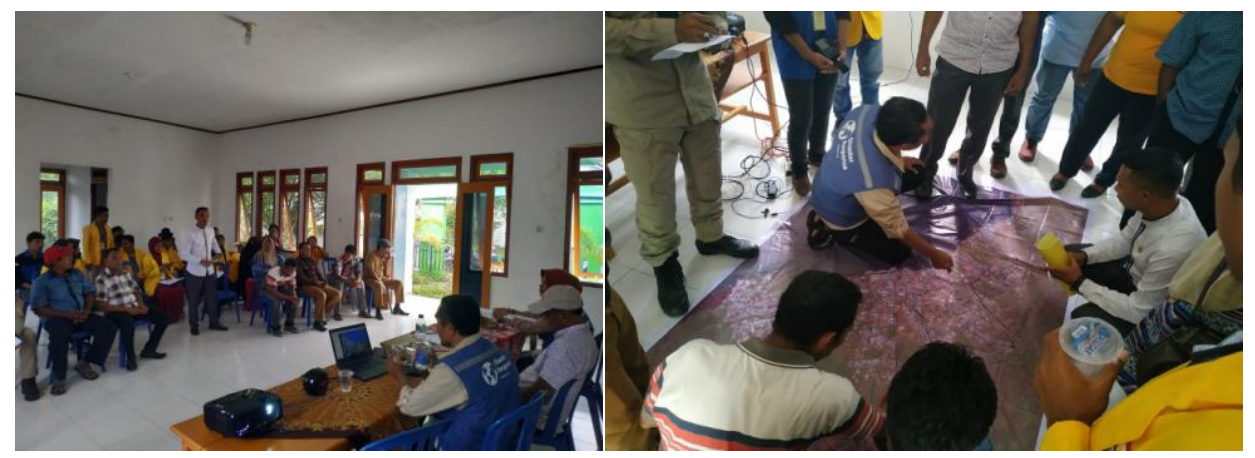

Gambar 2. Proses FGD dan Pemetaan Pertisipatif

Salah satu kebutuhan dasar yang diperlukan sebelum terjadi bencana adalah peta jalur evakuasi. Peta evakuasi ini berisikan informasi tentang wilayah-wilayah mana saja yang rawan terhadap suatu bencana dan wilayah mana saja yang aman terhadap suatu bencana. Peta evakuasi juga memuat jalur evakuasi yang mengarahkan masyarakat untuk menuju tempat yang aman, baik wilayah daratan maupun gedung yang dijadikan sebagai tempat evakuasi [3]. Untuk menghindari potensi bahaya bencana yang sangat besar, masyarakat perlu menetapkan dan menyepakati jalur-jalur evakuasi. Hal ini bertujuan agar upaya penyelamatan masyarakat pada waktu yang singkat dapat dilaksanakan dengan lancar dan terorganisir dengan baik. Dengan memperhatikan hal-hal tersebut dan masukan dari para peserta FGD (Gambar 2), maka penyusunan peta jalur evakuasi tsunami ini mempertimbangan beberapa hal; (1) Banyaknya 
orang yang beraktivitas di wilayah pesisir. Jumlah ini meliputi penduduk desa Babang yang menetap dan terbagi dalam 9 rukun tetangga (RT), masyarakat yang beraktivitas di pelabuhan, pasar, dan juga sekolah. Tentunya hal ini akan meningkatkan risiko korban jiwa. (2) Akses jalan yang tersedia. Akses jalan di desa Babang cukup memadai dimana hampir semua RT bisa dilalui akses jalan. (3) Kondisi topografi wilayah yang berbukit dan dataran tinggi yang mudah di jangkau. (4) Penentuan zona aman sebagai tempat berkumpul merupakan wilayah yang terbuka dan jauh dari jangakuan genangan air serta risiko bencana selanjutnya seperti longsor atau rekahan.

Berdasarkan pertimbangan tersebut maka peta evakuasi salah satunya diarahkan untuk menguraikan kepadatan warga dan mengarahkan masyarakat untuk mencapai wilayah yang aman sebagai tempat berkumpul dengan cepat. Di daerah yang berpenduduk padat, biasanya semua orang akan berlarian pada saat bersamaan. Hal ini tentunya akan menimbulkan kekacauan dan kemacetan lalu lintas yang tinggi sehingga dapat meningkatkan risiko bencana. Untuk itu mangatasi hal tersebut, menurut [10] perlu penerapan konsep evakuasi dengan dua zona evakuasi untuk menangani evakuasi bagi wilayah yang luas dan padat. Oleh karena itu, peta evakuasi yang disusun membagi jalur evakusi menjadi dua zona yaitu zona Timur dan zona Barat. Pembagian zona ini didasarkan pada jumlah RT dan letak wilayah. Untuk zona Timur meliputi warga RT 1, RT 2, RT 3, RT 4, dan RT 5 yang terletak di wilayah Timur desa diarahkan untuk mengikuti jalur Timur dengan lokasi pertemuan (titik kumpul) terletak pada areal yang kosong (lapangan terbuka). Sedangkan zona Barat meliputi warga RT 5, RT 6, RT 7, RT 8 dan RT 9 diarahkan untuk mengikuti jalur Barat dengan lokasi pertemuan berada di lapangan kantor Polsek Bacan Timur (Gambar 3).

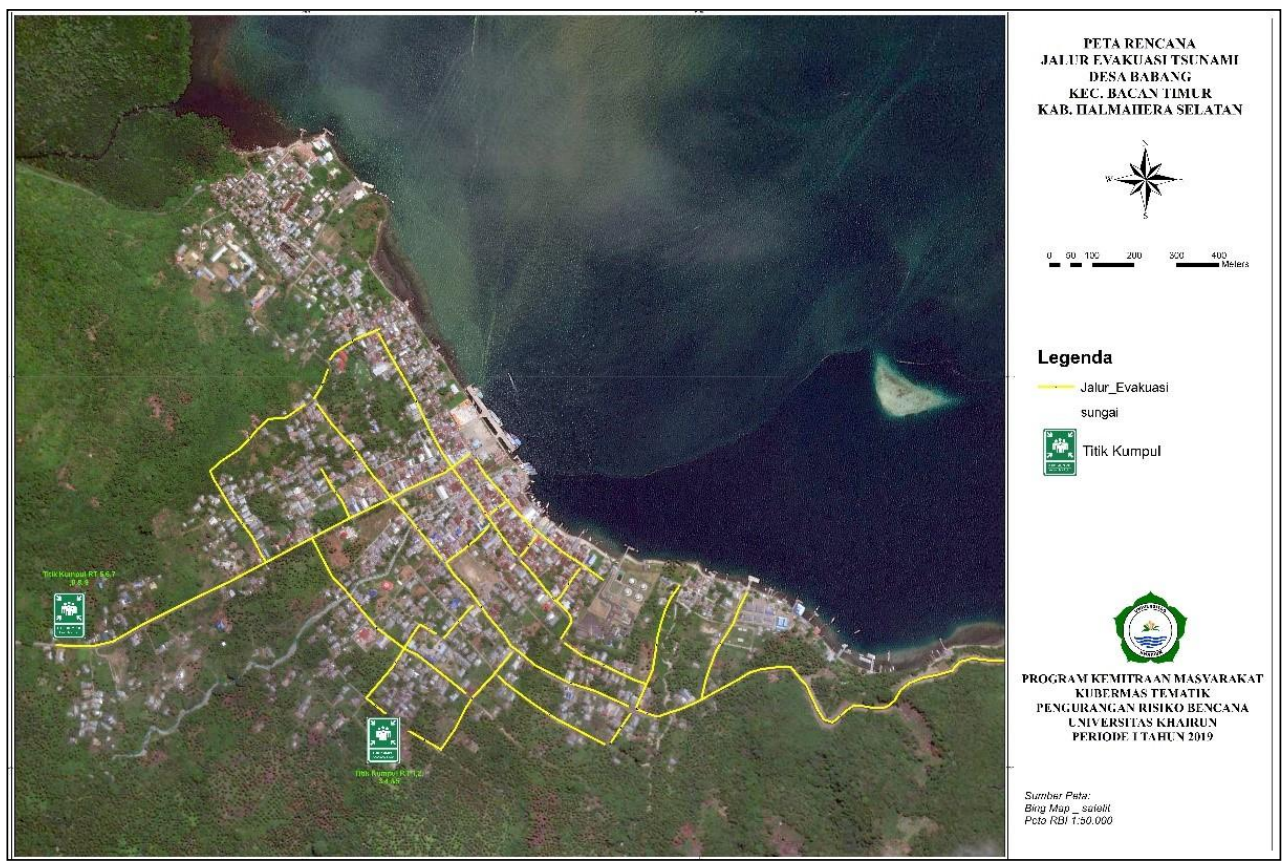

Gambar 3. Peta Jalur Evakuasi Tsunami Desa Babang

Berdasarkan masukan dari FGD bahwa jalur evakuasi yang dipilih adalah jalan yang dilalui oleh masyarakat sehari-hari dan memiliki akses tercepat. Hal ini untuk memudahkan masyarakat untuk bergerak dengan mudah menuju ke tempat lokasi pertemuan. Selain itu jalur 
yang dipilih diperkirakan aman dan jauh dari potensi bahaya lanjutan dan memiliki luasan yang cukup untuk dilalui oleh masyarakat dalam jumlah banyak pada waktu bersamaan. Sementara lokasi pertemuan yang ditentukan baik di zona Timur maupun zona Barat merupakan wilayah terbuka dengan ketinggian diatas 20 mdpl. Hal ini menjadi pertimbangan untuk bisa menampung kebutuhan pengungsi. Lokasi pertemuan yang dipilih harus memungkinkan para pelaku kedaruratan dapat melakukan pelayanan kebutuhan dasar warga seperti pelayanan kesehatan, bahan pangan, akomodasi, dan pertolongan pertama [10].

Hasil FGD juga mencatat beberapa hal yang sangat penting untuk dijadikan pertimbangan pada saat melakukan evakuasi; (1) Dalam melakukan evakuasi warga harus memutuskan apakah pada saat evakuasi warga masyarakat akan berjalan kaki atau menggunakan kendaraan. Di daerah yang penduduk padat dengan ruas jalan yang sempit, maka evakuasi harus dilakukan dengan berjalan kaki. Sedangkan penggunaan kendaraan bermotor hanya diperuntukkan untuk melewati akses jalan yang cukup lebar. (2) Warga masyarakat yang kesulitian melakukan evakuasi, dapat mencari gedung atau bangunan yang tinggi sebagai solusi tercepat untuk evakuasi. (3) Dukungan yang paling penting yang dibutuhkan warga masyarakat adalah peringatan dini dan arahan yang instruktif. Menurut [10], peringatan dini dan intsruksi yang tepat tentang apa yang harus dilakukan merupakan hal penting mengingat jeda antara kejadian tsunami dan waktu evakuasi yang sangat terbatas waktunya. Untuk system peringatan dini, warga masyarakat dapat menggunakan sumberdaya yang tersedia di desa seperti pengeras suara dari rumah ibadah, radio, dan alat komunikasi lainnya, (4) Perlu adanya sosialisasi dan latihan evakuasi yang terjadwal secara beraturan serta melibatkan semua pemangku kepentingan guna meningkatkan kewaspadaan dan kesipsiagaan masyarakat serta mengevaluasi peta jalur evakuasi jika terjadi perubahan.

\section{Kesimpulan}

Risiko tsunami merupakan tanggung jawab semua pemangku kepentingan, namun masyarakat dituntut untuk berperan aktif guna menghindari risiko bencana yang sangat besar. Hasil FGD dan pemaparan materi tentang bencana tsunami, mitigasi dan peta jalur evakuasi telah menambah pengetahuan dan pemahaman masyarakat akan wilayahnya yang berisiko bencana. Pemetaan jalur evakuasi telah disusun dengan menggunakan kearifan lokal yang dimiliki masyarakat berupa pengetahuan mengenai kondisi lingkungan sekitar serta dengan bantuan fasilitator untuk direpresentasi ke dalam bentuk peta digital. Peta jalur evakuasi yang disusun dengan tujuan untuk dapat memudahkan masyarakat dalam memahami kondisi wilayahnya dan mengarahkan warga masyarakat menuju daerah yang aman sebagai tempat berkumpul. Meskipun peta dibuat dengan pendekatan partisipatif, terdapat kemungkinan akan kesulitan penggunaan peta dari pihak masyarakat desa bila tidak dilakukan sosialisasi mengenai penggunaan peta secara luas kepada masyarakat.

\section{Daftar Pustaka}

[1] Ballantyne, P. (1991). Petrological constraints upon the provenance and genesis of the East Halmahera ophiolite. Journal of Southeast Asian Earth Sciences, 6(3-4), 259-269.

[2] Løvholt, F., Kühn, D., Bungum, H., Harbitz, C. B., \& Glimsdal, S. (2012). Historical tsunamis and present tsunami hazard in eastern Indonesia and the southern Philippines. Journal of Geophysical Research: Solid Earth, 117(B9).

[3] Bencana, B. N. P. (2012). Pedoman Sistem Peringatan Dini Berbasis Masyarakat.

[4] Twigg, J. (2009). Karakteristik Masyarakat yang Tahan Bencana.. 
[5] Wibowo, R. C., Karyanto, K., Zaenudin, A., \& Sarkowi, M. (2020). Peningkatan Partisipasi Masayarakat pada Studi Pemetaan Partisipatif dalam Pembuatan Jalur Evakuasi Bencana Tsunami di Desa Wisata Pagar Jaya. Sakai Sambayan Jurnal Pengabdian kepada Masyarakat, 4(1), 43-48..

[6] Paramita, A., \& Kristiana, L. (2013). Teknik Focus Group Discussion Dalam Penelitian Kualitatif. Buletin Penelitian Sistem Kesehatan, 16(2 Apr).

[7] Boissière, M., Duchelle, A. E., Atmadja, S., \& Simonet, G. (2019). Panduan teknis pelaksanaan pemetaan desa partisipatif. CIFOR.

[8] Wiwaha, A. A., Mei, E. T. W., \& Rachmawati, R. (2016). Perencanaan partisipatif jalur evakuasi dan titik kumpul Desa Ngargomulyo dalam upaya pengurangan resiko bencana Gunungapi Merapi. Journal of Regional and City Planning, 27(1), 34-48.

[9] Biro Pusat Statistik (2019) Kecamatan Bacan Timur Dalam Angka 2019. BPS Kabupaten Halmahera Selatan.

[10] H. Spahn, M. Hoppe, B. Usdianto, and H. Vidiarina, (2010) "Pedoman Perencanaan untuk Evakuasi Tsunami.".German-Indonesian Coorporation for Tsunami Early Warning System (GITEWS)

[11] Cadag, J. R. D., \& Gaillard, J. C. (2012). Integrating knowledge and actions in disaster risk reduction: the contribution of participatory mapping. Area, 44(1), 100-109.

[12] Groves, S. (2013). Knowledge, involvement and emergency preparedness.

[13] Bencana, B. N. P. (2018). Buku Pedoman Latihan Kesiapsiagaan Bencana: Membangun kesadaran, kewaspadaan dan kesiapsiagaan dalam menghadapi bencana..

[14] Lassa, J., Pujiono, P., Pristiyanto, D., Paripurno, E. T., Magatani, A., \& Parlan, H. (2009). Kiat Tepat Mengurangi Risiko Bencana. Pengelolaan Risiko Bencana Berbasis Komunitas (PRBBK).

[15] Edyanto, C. H. (2014). Partisipasi Masyarakat Sebagai Upaya Untuk Mengurangi Risiko Bencana Tsunami Di Daerah Pantai. Jurnal Sains dan Teknologi Indonesia, 16(3). 
Mohammad Ridwan Lessy, Rohima Wahyuningrum 